\title{
Changing Mental Models of the IT Professions: A Theoretical Framework
}

\author{
Denise E. Agosto, Su san Gasson, and Michael Atwood \\ Drexel University, Philadelphia, PA, USA
}

\author{
Denise.Agosto@ischool.drexel.edu \\ Susan.Gasson@ischool.drexel.edu \\ Michael.Atwood@ischool.drexel.edu
}

\section{Executive Summary}

It is widely recognized that the current and projected shortage of adequately-educated IT professionals could be greatly reduced if more female and minority students would major in IT disciplines, yet the dramatic under-representation of these populations appears to be worsening. This under-representation is reflected in Drexel University's College of Information Science \& Technology's undergraduate IT programs, which currently average just $9.7 \%$ female enrollment and just $9.7 \%$ non-Asian minority (Black, Hispanic, and Native American) enrollment.

As an initial step in working toward redressing this under-representation, the authors present a theoretical framework for increasing marginalized students' (women and minorities) participation in the study of IT. The Changing Mental Models Framework builds on existing gender and IT research, applying research findings to the practical realm of students' everyday lives. Most studies of why women avoid IT have demonstrated that females who are making career choices care a lot about "solving problems" and much less about "technology." Studies of minority students" career decision-making have developed similar conclusions. The Framework proposes that universities partner with local schools and business organizations to demonstrate that IT careers are directly tied to solving real-life problems and to show female and minority students real IT professionals at work, solving real problems that affect real people like them.

The Framework includes four dist inct components: mentoring, social cohesion an d pee $r$ support, role modeling, and curriculum re design. The article includes a detailed literat ure review of research relating to each of these four areas. The Framework focuses on fostering positive and diverse mental models of IT careers and IT professionals. This goal is significant because female and minority students tend to view IT careers and the people who work in computing-related jobs as overridingly white, male, and technology-focused. Consequently, these student populations require active and ongoing mentoring, social support, role modeling, and curriculum redesign to help them understand that they possess similar qualities to IT professionals and managers, and that these career paths are open to them

Material published as part of this publication, either on-line or in print, is copyrighted by the Informing Science Institute. Permission to make digital or paper copy ofpart or all of these works for personal or classroom use is granted without fee provided that the copies are not made or distributed for profit or commercial advantage AND that copies 1) bear this notice in full and 2) give the full citation on the first page. It is permissible to abstract these works so long as credit is given. To copy in all other cases orto republish or to post on a serveror to redistribute to lists requires specific permission and payment of a fee. Contact Publisher@InformingScience.org to request redistribution permission. and to others like them.

The next step in this process of working to increase female and minority IT enrollment and academic success will be to implement the proposed Framework and to monitor its effects on IT recruitment and retention. It is only through proactive social support measures such as the Framework proposed herethat we 
can bring under-represented female and minority populations more equally into the IT world.

Keywords: gender issues in IT, minority education, perceptions of IT, recruitment, retention, role models, mentoring.

\section{Introduction}

We are facing a crisis in information technology (IT) education. As a nation, we are not educating an appropriate cross-section of society to become the next generation of IT professionals, thereby shutting female and minority students out of IT careers. This "pipeline" effect (Camp, 1997) has been well-recognized now for more than a decade, yet it has not abated and is unlikely to do so in the near future. According to a Computer Research Association report (Vegso, 2005), "Alarmingly, the proportion of women who thought that they might major in CS (computer science) has fallen to levels unseen since the early 1970s." The National Science Foundation's Women, Minorities, and Persons with Disabilities in Science and Engineering (National Science Foundation, 2006) statistics indicate that while females obtained $57.6 \%$ of all bachelor's degrees in 2004 , they obtained just $25.2 \%$ of computer sciences-related undergraduate degrees. This percentage also reflects employment in this area.

These statistics also show that minorities (Asian/Pacific Islander, Black, Hispanic, and American Indian/Alaskan Native) together obtained $30.2 \%$ of undergraduate computer sciences-related degrees in 2004 (National Science Foundation, 2006). Whilethis number indicates fairly strong minority group participation, the high representation of Asian/Pacific Islander students $(43.0 \%$ of the CS undergraduate degrees obtained by minorities) masks the markedly lower participation of the remaining groups. Removing the Asian/P acific Islander group, Black, Hispanic, and American Indian/Alaskan Native students together obtained just $17.2 \%$ of the undergraduate computer sciences-related degrees conferred in 2004. This is a serious under-representation, as these same three groups together comprise $27.4 \%$ of the U.S. population as of 2005 (United States Census Bureau, 2007).

This problem is aggravated by a general national decline in student participation in IT-related undergraduate programs. Since the year 2000, we have seen a drop in the number of U.S. high school students aiming to study IT -related fields in college, and we have seen a subsequent decline in the number of undergraduates who are entering college as IT students (Vegso, 2005). Frauenheim (2004) reported that schools like MIT, Rutgers, and Carnegie Mellon have experienced a reduction in the number of freshmen in their IT programs. As a result, there is an insufficient pool of IT students to support the needs of industry, and there is an insufficient pool of IT students to sustain the healthy growth of future research and development.

It is widely recognized that the current and projected fut ure shortage of adequately-trained IT professionals could be greatly reduced if more female and minority college students would major in IT disciplines (e.g. Mayfield, 2001; McDonald, 2004; Pincus, 1997; Tapia \& Kvasny, 2004). Nonetheless, a dramatic under-representation of these populations in IT -related fields persists.

\section{An Example of the Problem: Declining IT Enrollment at Drexel University's College of Information Science \& Technology}

This downward enrollment trend is reflected in Drexel University's College of Information Science \& T echnology's (IST) undergraduate enrollment, which has fallen from a high of 127 freshmen in for the 2001-2002 academic year to just 54 freshman for the 2007-2008 academic year. The declining number of freshmen results in fewer graduates and fewer students entering the IT-related fields. Currently, IST undergraduate programs average just $9.7 \%$ female enroll- 
ment and just 9.7\% non-Asian minority (Black, Hispanic, and Native Indian) enrollment. Table 1 shows current enrollment statistics by gender.

Table 1: IST Undergraduate Male/Female Enrollment for AY2007-2008.

\begin{tabular}{|l|c|c|}
\hline Ge nder & Number of Stu dents & Percen tage \\
\hline Male & 308 & $90.3 \%$ \\
\hline Female & 33 & $9.7 \%$ \\
\hline Total En rollment & $\mathbf{3 4 1}$ & $\mathbf{1 0 0 . 0} \%$ \\
\hline
\end{tabular}

At IST, non-Asian minorities are similarly under-represented. Table 2 breaks these students down according to self-reported ethnic/racial designation.

Table 2: IST Un de rgraduate Ethnic/Racial Enrollment for AY2007-2008.

\begin{tabular}{|l|c|c|}
\hline Eth nic/Racial Designation & Num ber of Stu dents & Percen tage \\
\hline $\begin{array}{l}\text { African American/Black Non- } \\
\text { Hispanic }\end{array}$ & 23 & $6.7 \%$ \\
\hline Asian or Pacific Islander & & $17.9 \%$ \\
\hline Mexican American & 1 & $0.3 \%$ \\
\hline Puerto Rican American - Mainland & 2 & $0.6 \%$ \\
\hline Not reported & 10 & $2.9 \%$ \\
\hline Other Hispanic & 7 & $2.1 \%$ \\
\hline White Non-Hispanic & 237 & $69.5 \%$ \\
\hline Total en rollment & $\mathbf{3 4 1}$ & $\mathbf{1 0 0 . 0 \%}$ \\
\hline
\end{tabular}

The great irony in these statistics is that IST sits in the middle of a predominately minority city. Philadelphia residents are 55.3\% Black, Hispanic, and American Indian/Alaskan Native, which is morethan twice the $27.4 \%$ national average (United States Census Bureau, 2007). Philadelphia also has a slight ly higher than average female population, $53.7 \%$, as opposed to the national average of 51.0\% (United States Census Bureau, 2007). Yet even though it is located in this incredibly diverse environment, and even though its undergraduate programs have a largely local draw, IST cannot attract a representative proportion of female and/or minority students to its IT-related undergraduate degree programs.

Why do these marginalized groups hesitate to participate in the study of IT? The problem is largely societal. Solving it requires cooperation with agencies and organizations outside of the College and the University. Our response to the problem is to treat these groups as marginalized populations, rather than as specific populations with different needs. We are arguing that we want to include them in general programs of education, rather than to target them with separate programs. Below we present a theoretical framework for changing marginalized students groups' 
mental models of the IT professions, thereby increasing their desire to participate in the study of IT. The Changing Mental Models Framework is based the extensive body of existing gender and technology research, bringing research ideas int o the practical realm of students' everyday lives. The Framework is not unique to our College or University. It can be used by any academic institutions interested in increasing marginalized student group participation in IT. A review of the related literature follows the presentation of the Framework.

\section{Changing Mental Models: The Framework}

The Changing Mental Models Framework builds on existing gender and IT and minorities and IT research, applying research findings to the practical realm of students' everyday lives. As marginalized student populations, women and minorities have many shared needs, and the same kinds of mechanisms can lead to changing their mental models of IT. Most studies of why women avoid IT have demonstrated that females who are making career choices care a lot about "solving problems" and much less about "technology" (e.g. Agosto, 2001 b; Beyer, Rynes, \& Haller, 2004). Studies of minority students' career decision-making have developed similar conclusions (e.g. Burge \& Suarez, 2005). The Framework recommends partnering with educational and business organizations to demonstrate that IT careers are directly tied to solving real-life problems and to show female and minority students real IT professionals at work, solving real problems that affect people like them.

The Framework focuses on fostering positive and diverse mental models of IT careers and IT professionals. This goal is significant because female and minority students tend to view IT careers and the people who work in computing-related jobs as overridingly white, male, and technologyfocused. They require active and ongoing mentoring to understand that they possess similar qualities to IT professionals and managers and that these career paths are open to them.

Moreover, there is an increasing shift from groups and hierarchies as the dominant mode of social organization in business corporations to network models, with a commensurate shift from centralized to decentralized decision processes (Benkler, 2006). Individuals who feel unable to participate in networked decision-making or who feel uncomfortable in online communities are likely to be severely disadvantaged. Female and minority students are more likely than their white, male peer students to feel isolated or inadequate in the use of information technologies. The Framework focuses on creating a sense of inclusion and a facility with technology by providing support from a peer community. While the framework could be used to increase broad-based student participation in IT, regardless of gender or ethnic/racial group membership, it is its focus on promoting the feeling of inclusion for marginalized populations that makes it especially well-suited to increasing female and minority IT participation. The Framework also focuses on developing undergraduate curricula that meet the needs of students from disadvantaged groups. If students' experience of the academic program that they selected is unsatisfactory, they may feel disempowered.

The Framework appears in Figure 1: The Changing Mental Models Framework. 
Agosto, Gasson, \& Atwood

\section{Present a Variety of Positive Role Models}

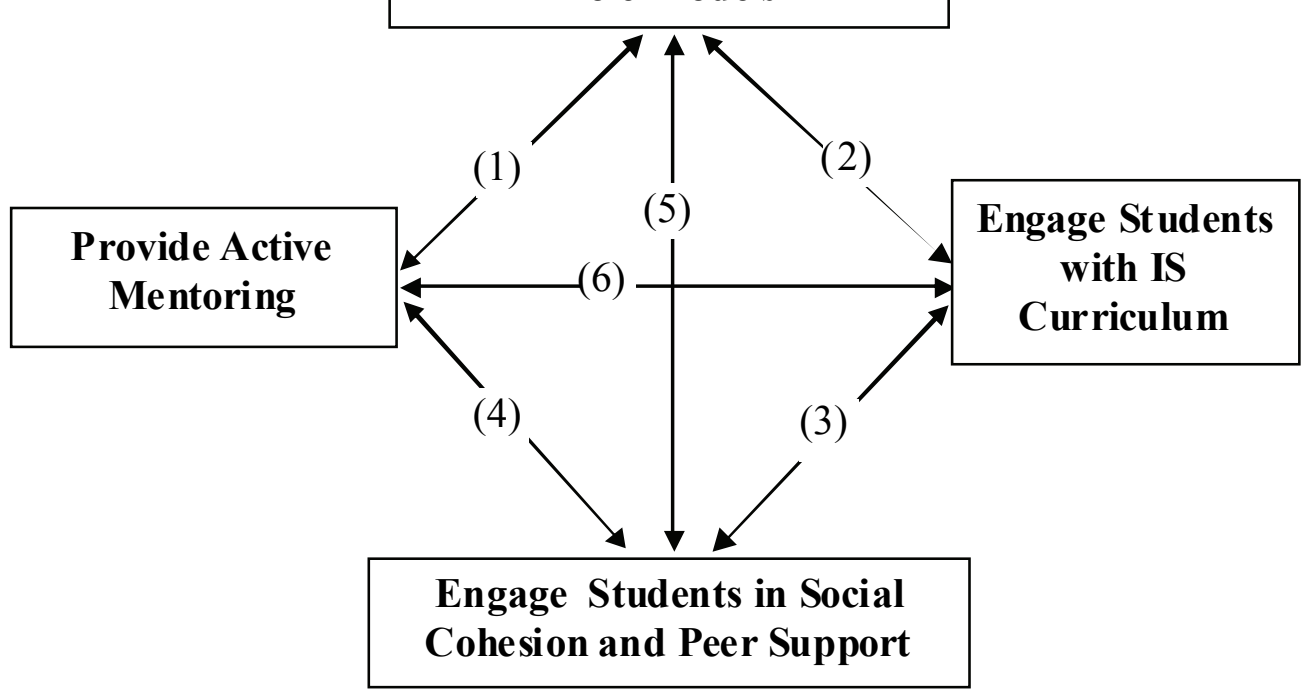

\section{Figure 1: Changing Mental Models: A Theoretical Framework for Engaging Marginalized Populations in IT Education}

The framework above presents four central elements from the literature on dealing with marginalized populations in education. The key elements of the framework arethe synergies between the elements; this framework suggests an ecological approach to education, where none of the elements is sufficient on its own. We suggest that this framework could be operationalized through the integrative relationships between elements. For integrative mechanism (1), we propose that active ment oring can be used to present a variety of role models through Middle and High School outreach activities. For mechanism (2), we would suggest that we can present a variety of role models to engage students in curriculum redesign through a University Lunch Club, where students from marginalized groups meet with a variety of female and minority-group role models, to motivate them to engage with technology subject areas. Their identification with the curriculum could be strengthened through mechanism (3), which engages students in social cohesion and peer support through reviewing and suggesting changes to the curriculum, as experienced by marginalized student groups. For example, female students often report that current curriculum delivery mechanisms are biased towards boys who, though high school clubs, have more technical experience than they. Engaging female students in curriculum redesign produces more activity-based courses that rely less on existing technical expertise. For mechanism (4), we suggest that involving students in school \& university online communities provides social cohesion and support through peer mentoring. This can be combined with guided mentoring in mechanism (5) to provide social cohesion and wider identification with IT professionals by introducing students to and building mentor relationships with IT professionals. Finally, mechanism(6) engages students with the IS curriculum and provides active mentoring through presenting video cases, where IS professionals can speak to the skills and expertise that they have found critical in maintaining a successful career. Any one of these mechanisms alone will just deal with part of the problem. It is through the integration of these six cohesion mechanisms that we propose to engage students from marginalized populations, to the extent that they identify with their peer communities of IS professionals and IS students. 


\section{The Research Underlying the Framework}

Based on a large body of related research, researchers and educators have a good idea of the major reasons why women and monitories hesitateto enter IT-related professions. (See Cohoon \& Aspray, 2006, for detailed discussions of some of these studies.) There have been several significant studies of why women avoid IT careers, and most of them point to the fact that young women who are making career choices care a lot about "solving problems" and much less about "technology" (e.g. Agosto, 2001b; Beyer et al., 2004). These studies indicate that young women see other disciplines, such as education or psychology, as leading to careers that are more focused on solving human problems, and consequently they find these fields more attractive. Studies of minority students' career decision-making have had similar conclusions (e.g. Burge, \& Suarez, 2005).

The overarching problem is that females' and minorities' mental models of IT tend to create inaccurate and unappealing pictures of IT education and of IT careers (Rettenmayer, Berry, \& Ellis, 2007). Agosto's (2001b, 2004) research has shown that adolescent girls tend to be interested in computers primarily as tools for communication with other humans, rather than as tools for technological achievement, and that they tend to view the IT fields as de-socialized technological spaces. This is a common finding among gender andtechnology researchers (e.g. Brunner, Bennett, \& Honey, 1998; Honey et al., 1991; Schofield, 1995; Subrahmanyam \& Greenfield, 1998; Turkle, 1988). Similarly, Jackson, Ervin, Gardner, and Schmitt (2001) found that female undergraduates used the Intemet primarily for sending e-mail, whereas undergraduate males used the Intemet primarily for searching for information. Other researchers have found that females' deep interest in human communication and human relationships stands at odds with their view of computer scientists as working in social isolation (American Association of University Women, 2000).

The Framework is built upon four streams of research connected to female and minority students' mental models of IT: IT mentoring for women and minorities, social cohesion and peer support for female andminority IT students, IT role models, and IT curriculum redesign.

\section{Mentoring}

Mentoring and role modeling can be effectivetools for changing students' mental models of IT . Verbick (2002) described the ment oring role in simple terms: a mentor"can advise the young woman of any pitfalls to avoid and can be an excellent support person during times of trouble and change" (p. 245). It is the personal aspect of the mentoring relationship that is key, and it is this personal contact that differentiates mentors from role models. Role models can be provided by images and discussions in the media or in classrooms, by shared mental models among social groups, or by casual acquaintances.

Mentoring is not only about helping students to leam, it is about helping students learn to learn. While a student could learn on his or her own, leaming is aided by having a mentor. Leaming to learn, however, can rarely be accomplished without a mentor. Learning requires that the student show some mastery of the concepts presented in the classroom. Learning to learn, on the other hand, requires that the student understand how these concepts can be applied and modified to fit the world of practice. This requires someone who understands that world of practice. Lave and Wenger (1991) define professional practice as being "situated" in the context of action. We cannot understand how to practice our profession without an understanding of how our behavior is interpreted as professional or unprofessional in a typical context of practice.

Donald Schön's (1983) The Reflective Practitioner presents a theory of how professionals learn. The Reflective Practitioner is based upon Schön's conviction that universities are not devoted to "the production and distribution of fundamental knowledge in general, but in a particular episte- 
mology that fosters selective inattention to practical competence and professional artistry" (preface). This claim forms the foundation for his discussion of how professionals think when situations arise that are a surprise or do not fit a known model or method for finding a solution. The everyday work of a professional is in the "tacit knowing-in-action" (pg. 49). It is how we do things somewhat automatically without consciously thinking about them. Schön distinguishes reflection-in-action as an aspect of professional practice that comes about when a practitioner encounters an unexpected, surprising, or unknown situation for which their knowledge base has no frame. As the practitioner tries to make sense of this situation, a reflection takes place upon the "understandings, which have been implicit in his action." This artful manner of inquiry by which practitioners sometimes deal with uncertainty Schön calls "a reflective conversation with the situation" (pg. 268). Teaching reflection-in-action as way to learn to learn is discussed in more detail in Educating the Reflective Practitioner (Schön, 1990).

Professional practice is "situated" in the context of action. We cannot understand how to practice our profession without an understanding of what constitutes an appropriate way to solve various types of problems in a typical context of practice. We cannot learn how to problem-solve without an understanding of what constitutes socially-acceptable - and therefore "professional" careerenhancing - ways of presenting a solution in a given community of practice (Lave \& Wenger 1991). Having a mentor is key to learning how to leam and to leaming how to behave professionally.

But, while mentors help students leam to leam, doing so also improves the mentor's skills. There is an interplay between our self-understanding and our understanding of the world that is realized through relating the "parts" of our daily practice in problem-solving to the "whole" in our interpretation of how the world works. A hermeneutic circle of self-understanding is realized through assertion, where we explain the workings of the world to others (Heidegger, 1962). Explanations help us to understand practice better, which makes us better professionals, as well as better mentors. So the benefits of a goodmentoring program extend to mentors as well as to mentees:

"In corporate or academic settings, mentoring, in general, and for under-represented minority groups, in particular, has proven to result in desirable outcomes. Davis and Rodela (1997) have detailed these consequences: 1 . Higher productivity and performance rat ings for both the mentor and protégé; 2. More accurate selection and training of new personnel; 3. Greater retention of highly qualified people; and 4. A greater probability of a person's being promoted to a senior rank." (Payton \& White, 2003, p. 125)

A study of students in a Stanford CS course reinforced the importance of mentoring: "Only students who knew adults involved in computing had a notion of options for computer science graduates that extended beyond the images of a solitary, 'Office Space' coder developing lines of script" (Zur, Irani, Barker, \& Guzdial, 2005, p. 64). Othman and Latih (2006) found that the high percentage of female role models and mentors in Malaysia results in significantly higher female CS and IT participation at the undergraduate level. Katz, Allbritton, Aronis, Wilson, and Soffa (2006) found mentors to be an indicat or of undergraduate academic success in the computerrelated disciplines.

Stephenson, Miguel, Peckham, Hervé, and Hutt (2007) have shown that mentoring leads to increased IT student retention at the undergraduate level. Payton and Jackson (1999) emphasize the importance of minority faculty as mentors in IT academic retention efforts. They studied IT minority doctoral students' socio-cultural needs for educational success. Doctoral students' main barriers to success included "minimal faculty support, social isolation and the need for minority mentors" (p. 32), indicating that the need for mentorship continues beyond the undergraduate years. Indeed, "the largest concern of the students was the scarcity of minority IS faculty for 
mentorship" (p. 32). However, Payton and White (2003) pointed to the serious shortage of African American mentors in the IT professions, which prevents students from finding mentors on their own without formal support structures such as the one proposed here. Mentoring for women and minorities is also crucial to retention at the professional level, wherethese populations continue to be under-represented (Tapia \& Kvasny, 2004).

\section{Implications for implementing mentoring as a component of the framework}

This research suggests that providing formal faculty and IT professional mentoring relationships for female and minority undergraduate IT students can increase IT student retention. Ideally, mentoring should be a part of a larger effort to provide badly needed support and encouragement for under-represented student populations.

\section{Social Cohesion and Peer Support}

Another element of female and minority students' mental models of IT is the misperception that IT disciplines and professions exist in social isolation. Peer-support from other female students has a significant effect on persistence and retention of female students at the undergraduate level (Cohoon, 2001). Agosto's (2001b) work with high school females interested in science and mathematics found them to be uninterested in pursuing computer-related careers for this very reason: a distaste for working alone. The young women were much more interested in careers in medicine or biology; careers that they felt involvedmore collaborative work and more interaction with peers. Beyer et al. (2004) surveyed 567 college freshmen about their attitudes toward CS and their decisions whether or not totake CS courses. They found the subjects generally to hold negative stereotypical views of CS students as "unsociable and nerdy" (p. 26), which they identified as a deterrent to women studying CS. This view of the IT world as unwelcoming to females continues at the professional level. Perelman (2007) found that only about half of the 2,000 female IT professionals she surveyed "believed their company offers a favorable environment for women."

This is critical as we see a new generation of "Millennial students" emerge. Born between 1979 and 1994, Millennials comprise the bulk of today's undergraduates and will continue to do so for much of the next decade. Their relationships to technology are different fromthat of previous generations. Technology, and ICT use particularly, plays a much larger role in their everyday lives (Brown, 2000; Oblinger \& Oblinger, 2006). They have a stronger preference for collaborative work, experiential and inductive leaming opportunities, and multi-tasking than previous generations of students. These are "digital natives" (Prensky 2001), whose uses of technology are embedded in their daily lives and who prioritize social uses of technology over instrumental uses. While these students are knowledgeable in the use of technology, they are extremely naïve about how such technologies are constructed. They view technology design and programming as "geeky" and anti-social (Kvavik, 2005). Peer-support is even more critical for this generation of students than for previous generations - and is especially critical for minority students. A report by the Coalition to Diversify Computing concluded that:

"Minority students may also lack social outlets in which they feel comfortable; and anecdotal evidence suggests that social factors can play a large role in how much a student enjoys the graduate experience and how well he or she succeeds. Communities are perhaps the most effective means for teaching these lessons, and peer support is probably the most effectivetype of support. Sometimes the students can form such communities on their own, but it behooves the department to take an active interest in and provide aid to these communities." (Aspray \& Bernat, 2000, p. 19) 
Student community building programs have also been shown to lead to increased participation in CS and IT for females and minorities. For example, Denner, Wemer, Bean, and Campe (2005) have used electronic game design clubs with middle school girls and have had success at increasing their computer confidence and skills. Dobosenski (2001) has had similar success with fifth grade girls' computer clubs. Beyer, Rynes, Perrault, Hay, and Haller (2003) found friends and family who support females' interests in IT to have a significant impact on their college major selections, showing the importance of supportive social networks in IT program recruitment.

Agosto and Hughes-Hassell's (2008) current research into minority teens' information seeking and use shows that, unlike middle class white/Caucasian teens who are generally tech-savvy computer users, low-income minority teens tend to favor telephones and face-to-face communication over computers, viewing computers as an anti-social information medium (Agosto \& Hughes-Hassell, 2005). This strong desire for close-knit social communities can result in a distaste for supposedly "anti-social" IT careers.

These misconceptions about the anti-social nature of computer-related careers add up to female and minority students' reduced interest in studying IT disciplines in college. Removing this attitudinal barrier is crucial for increasing females' and minorities' participation in IT, as interest is a key component of student advancement, especially in the case of groups that are under-

represented in STEM(science, technology, engineering, andmathematics) disciplines (Campbell, Jolly, Hoey, \& Perman, 2002).

\section{Implications for implementing social cohesion and peer support as a component of the framework}

As shown above, providing IT community building opportunities can change students' misperceptions of computer work as anti-social work and increase their interest in IT. These concepts can be translated into providing online and face-to-face opportunities for social networking with peers, with IT professionals, and with IT faculty.

\section{Role Models}

A crucial part of female and minority students' negative mental models of IT is a lack of appropriate role models. In a telephone survey of 652 college-bound high school students, Jepson and Perl (2002) found the top six reasons why females were less likely than males to pursue IT careers to be: "not enough role models," "women have other interests," young women "don't know about the industry," young women have "limited opportunity," "negative media," and the perception that computer-related careers are "too nerdy." Agosto's (2001a) work confirms this idea. Thomas and Allen (2006) found that a majority ofthe female IT students at an Australian university could not name any female IT role models. The reason for this shortage is simple: most IT professionals are male, meaning that most of the IT professionals young women see and hear about are men. The lack of visible female role models makes females feel that STEM careers are not open to women (Kekelis, Ancheta, \& Countryman, 2005). Based on an extensive metaanalysis, Adya \& Kaiser (2005) identified role models as a major factor in young women's career decision-making, a finding echoed by Guzman, Sharif, Blanchard, Ellis, and Stanton (2005).

Similarly, the paucity of non-Asian minority IT professionals in the U.S. discourages minority students from entering the IT fields, thereby perpetuating their under-representation (May \& Chubin, 2003). Payton (2004) surveyed the IT field and found that the percentage of African American IT professionals is shrinking: "While African Americans represented 10.9 percent of the U.S. workforce in 2002, the percentage of African American IT professionals declined from 9.1 percent to 8.2 percent" (p. 4). She tied this under-representation to a lack of role models and a lack of networking opportunities and to misperceptions about the nature of IT careers. 
The lack of appropriate role models is compounded by females' negative perceptions of computers and computer-related professions. Clarke and Teague (1994) have tied historic reductions in female participation in computing in Australia to negative public and classroom images of computers-making the computer a kind of anti-role model for young women. Indeed, many females hold a view of computers as "boys' toys" (Cassell \& Jenkins, 1998, p. 14), and of the computer-related professions as unwelcoming to women. Margolis and Fisher (2002) showed that social, educational, and familial factors led young men and women to view CS and IT as male domains, a view that makes young women feel locked out of computer-related professions and serves as an attitudinal deterrent to the pursuit of IT degrees. Margolis and Fisher's findings corresponded to American Association of University Women (1998) researchers' findings that high school females, even those who are frequent computer users, eschewthe "computer culture," making them less likely to pursue IT careers.

As further proof of this perception of the computer-related disciplines as male domains, Moorman and Johnson (2003) surveyed 941 male and female U. S. high school students taking advanced mathematics and CS classes about their computer skills, computing habits, likely college majors, perceptions of CS, and perceptions of computer scientists. They found only $16.8 \%$ of the females, as opposed to $48.2 \%$ of the males, were interested in pursuing CS degrees. The researchers also found a similar gender gap in computer confidence, with $18.1 \%$ of the females and $54.6 \%$ of the males rating their skills as advanced. The authors concluded that students of both sexes generally viewed CS as a male domain absent of female role models, which prevented the females from seeing themselves as future CS majors. Similarly, Cohoon (2007) has shown that female graduate students in IT fields tend to have less confidence that they can achieve their educational goals and less confidence in asking questions in class than do male students. Madigan, Goodfellow, \& Stone (2007) have had similar findings with first-year CS students.

Just as many young women view the computer-related professions as a male domain that is unwelcoming to women, many people of color view these fields as a "white" domain that is unwelcoming to minorities. As Payton (2004) explained, the paucity of African American IT professionals leads young African American students to develop a "perception of IT as a career for White males" (p. 4). She suggested that this perception helps to perpetuate the low percentage of people of color working in IT jobs.

The good news is that providing positive female and minority role models can counteract these negative representations and make computer-related careers seem more achievable. As Kekelis et al. (2005) explained, "Role models help combat stereotyped images and also communicate information about the work and the steps needed to prepare for a [CS or IT] career" (p. 18). Joshi and Schmidt (2006) found female undergraduates to hold negative perceptions of IT-related professions, but they showed that these negative perceptions are largely based in stereotypes and can improve significantly with exposure and accurate information.

Having a role model is not just about having someone to look up to; it is about having colleagues in your community. In their book The Social Life of Information, Brown and Duguid (2000) highlight the fact that information exists within a social context and, once that context is lost, the information loses value rapidly. For example, a group that generates a document shares certain background knowledge and beliefs. Since this knowledge and these beliefs are shared among group members, it is not necessary to explicitly state them in the document. However, if this knowledge or these beliefs were to change, the document could not be understood. Absent the community, information ceases to exist.

In such communities of practice (Lave \& Wenger, 1991) learning results from working in a community and in learning to speak the vocabulary ofthe community. Successful organizational memories have been described, for example, for copier repair technicians (Orr, 1996) and mid- 
wives (Jordan, 1989). In these and similar cases, members of an organization learn by participating in the activities of the organization.

\section{Implications for implementing role modeling as a component of the framework}

This research reveals the important of providing positive role models in order to change students' mental models of IT. It suggests that providing female and minority IT role models can show students that women andminorities can and do enter computer-related professions, thereby breaking down their perceptions of IT professions as an exclusionary club for white males.

\section{Curriculum Redesign}

Females' and minorities' mental models of the IT world also tend to include negative views of the nature of IT coursework. A number of studies have shown that curriculum redesign can increase recruitment and retention if the redesign is based on students' learning style preferences and social interests (Kirk \& Zander, 2002). Lewis, McKay, and Lang (2006) have argued the importance of curriculum redesign in the recruitment and retention of female IT students. Geier et al. (2004) have shown that curriculum redesign helps to reduce the minority student achievement gap. Frieze, Blum, and Dias (2006) stressed that female under-representation is a social issue, not an intellectual one, and that the social support structures of the curriculum morethan the contents of the courses need to be changed in order to increase female student retention.

However, there are some course content changes that do result in increased recruitment and retention. Georgia Tech researchers have shown that making IT courses more clearly tied to using technology to solving societal problems increases their appeal to both female and minority students:

"At Georgia Tech, we created a new introductory course Introduction to Media Computation that teaches introductory computer science in the context of manipulating media--a useful application of computers that students recognize.... With the new course, we have some $90 \%$ of the students succeeding at the class, including women and minorities-and asking for more computing courses! The content of the new courses that we are creating for these students is computer science, but by explicitly starting from the computing, we create a sequence that attracts a different and wider range of students." (Guzdial, quoted in Zur et al., 2005, p. 64)

Returning to Margolis and Fisher's (2002) argument, curriculum redesign should also focus on the building of social support networks. One method of achieving social cohesion is by building the study and discussion of socio-cultural issues into the IT curriculum. Dudley-Sponaugle, Goode, Schroeder-Thomas, and Trajkovski (2003) have found that introducing the topic of gender and minorities in IT education and in the IT professions into general IT courses can provide badly needed social support for female and minority students. Gasson and Agosto (2008) have suggested that facilitating social interaction during academic work activities is especially important for helping today's undergraduates learn.

Little et al. (2001) showed that socio-cultural issues within the IT industry, including gender and diversity issues, should be a part of any curriculum intended to attract and retain marginalized groups, as "it is not enough for graduates to havetechnical capabilities; they also will work in an environment with multicultural customers and clients" (p. 137). The authors explained that in order for IT graduates to be productive and successful in an increasingly diverse world IT market, IT graduates must be able to: 
- "Be knowledgeable about the demographics of the workplace, especially as it concerns cultural issues, including gender,

- Understand efforts to create successful team building with multicultural members and trends of multinational out sourcing of projects,

- Show awareness of industry trends for cultural differences, especially as it may apply to the use of workers in an immigrant status,

- Understand trade-offs of gender issues as they apply to team considerations,

- Be considerate of and attentive to the perceptions of the user who may have cultural and gender sensitivities" (p. 137).

The authors provided examples of classroom exercises that can be used to address each of these crucial areas, areas often omitted from traditional IT curricula.

Blum and Frieze (2005) have argued that computer-related courses should not be limited to programming skills but should present a broader view of computing to students. Finally, Zur, et al. (2005) have shown that the IT gender gap is strongly tied to the content of individual courses and that research-based course redesign can go a long way toward redressing the gap.

How should these changes be made? We argue that the responsibility for curriculum design resides not just with the instructors but is shared equally by instructors and students. In WorkOriented Design of Computer Artifacts, Pelle Ehn (1989) notes that the design of systems to function in complex situations, such as large technology-oriented companies or interdisciplinary design domains, requires a deep understanding not only of the application domain, but also of the practice of the people who will use the systems. This belief is the core the user-centered design approach that dominates the human-computer interaction community. We argue that this approach is also appropriate for curriculum design. A central theme of Ehn's approach to design is that the users and developers must work closely together. Ehn's approach is sometimes called the Scandinavian approach to design, or participat ory design, as well as work-oriented design.

\section{Implications for implementing curriculum redesign as a component of the framework}

A critical component of the Framework is careful curriculum redesign to incorporate sociocultural aspects of IT into the undergraduate curriculum and to create course-based structures for social net working and social cohesion among female and minority students. Such efforts can make considerable headway into changing females' andminority students' mental models of IT.

\section{Conclusion}

The research underlying the Framework suggests that bringing students to IT work places to observe IT managers working collaboratively and using information technologies to solve real problems that affect real people's everyday lives can make IT careers much more at tractive to young women andminorities. An underlying goal of the Framework is to put female and minority students into direct communication with active IT professionals who will serve as role models and mentors. As a result, students will come to see that most IT-related jobs are directly tied to solving real-life problems, and it will start them thinking about computer technology as a means for human problem solving and for collaborative work. The Framework couples these ideas of IT mentoring and role modeling with the creation of inst itutionally-supported formal structures for enabling social cohesion and peer group building. Lastly, it suggests that support for all of these measures must be built into to IT curriculum as well. 
The next step in this ongoing process will be to implement the Changing Mental Models Framework at IST as a test case and to monit or its effects on female and minority IT recruitment and retention. It is hoped that it will lead to the development of an ongoing collaborative IT community that will encourage young women andminorities to participate more equally in the increasingly-important world of information technology, both locally at IST and beyond our College as well. As Fountain (2000) has argued, making women equal players in the design of technology will broaden the range of available technological applications, products, and practices, thereby greatly benefiting our global society. The same is true of bringing more minority students into IT-related fields.

\section{References}

Adya, M. \& Kaiser, K. M. (2005). Early determinants of women in the $\Pi$ workforce: A model of girls' career choices. Information Technology \& People, 18(3), 230-258.

Agosto, D. E. (2001a). Bounded rationality and satisficing in young people's evaluation of World Wide Web resources. Unpublished doctoral dissertation, Rutgers, The State University of New Jers ey, New Brunswick.

Agosto, D. E. (2001b). Propelling young women into the cyber age: Gender considerations in the evaluation of Web-based information. School Library Media Research, 4. Retrieved from http://www.ala.org/aasl/SLMR/vol4/gender/gender.html

Agosto, D. E. (2004). Using gender schema theory to examine gender equity in computing: A preliminary study. Journal of Women and Minorities in Science and Engineering, 10, 37-53.

Agosto, D. E., \& Hughes-Hassell, S. (2005). People, places, and questions: An investigation of the everyday life in formation-s eeking behaviors of urban young adults. Library \& Information Science Research, 27, 141-163.

Agosto, D. E., \& Hughes-Hassell, S. (2008). The role of information communication technology in the lives of low-income minority teenagers. Unpublished working manuscript.

American Associ ation of University Women. (1998). Gender gaps: Where schools still fail our children. New York: Marlowe.

American Association of University Women. (2000). Tech-Savvy: Educating girls in the new computer age. Washington, DC: AAUW.

Aspray, W., \& Bernat, A. (2000). Recruitment and retention of underrepresented minority graduate students in computer science. Washington DC: Computing Research Association.

Benkler, Y. (2006). The wealth of networks: How social production transforms markets and freedom. New Haven, CT: Yale University Press.

Beyer, S., Rynes, K., \& Haller, S. (2004). Deterrents to women taking computer science courses. IEEE Technology and Society Magazine, 23, 21-28.

Beyer, S., Rynes, K., Perrault, J., Hay, K. \& Haller, S. (2003). Gender differences in computer science students. SIGCSE' '03, Feb 19-23, Reno, Nevada.

Blum, L., \& Frieze, C. (2005). In a more balanced computer science environment, similarity is the difference and computer science is the winner. Computing Research News, 17(3).

Brown, J. S. (2000). Growing up digital. Change 32(2), 10-11.

Brown, J. S., \& Duguid, P. (2000). The social life of information. Boston: Harvard Business School Press.

Brunner, C., Bennett, D., \& Honey, M. (1998). Girl games and technological desire. In J. Cassell, \& H. Jenkins (Eds.), From Barbie to Mortal Kombat: Gender and computer games (pp. 72-88). Cambridge, MA: MIT. 
Burge, J. D., \& Suarez, T. L. (2005). Preliminary analysis of factors affecting women and African Americans in the computing sciences. TAPIA '05. Oct 19-22, Albuquerque, New Mexico.

Camp, T. (1997). The incredible shrinking pipeline. Communications of the ACM, 40, 103-11.

Campbell, P. B., Jolly, E., Hoey, L. \& Perman, L. K. (2002). Upping the numbers: Using research-based decision making to increase diversity in the quantitative disciplines. Commissioned by the GE Fund, January 2002. Available at www.ge.com/found ation/GEFund UppingNumbers.pdf

Cassell, J., \& Jenkins, H. (1998). Chess for girls? Feminism and computer games. In J. Cassell \& H. Jenkins (Eds.), From Barbie to Mortal Kombat: Gender and computer games (pp. 2-45). Cambridge, MA: MIT.

Clarke, V. A., \& Teague, G. J. (1994). A psychological perspective on gender differences in computing participation. Technical Symposium on Computer Science Education. Proceedings of the Twenty-Fifth SIGCSE Symposium on Computer Science Education, 258 - 262.

Cohoon, J. M. (2001). Towards improving female retention in the computer science major. Communications of the ACM, 44(5), 108-114.

Cohoon, J. M. (2007). Gendered experiences of computing graduate programs. Proceedings of the 38th SIGCSE Technical Symposium on Computer Science Education, 39, Covington, Kentucky, 546 - 550.

Cohoon, J. M., \& Aspray, W. (2006). Women and information technology: Research on underrepresentation. Cambridge, MA: MIT Press.

Davis, J., \& Rodela, E. S. (1997). Mentoring for the Hispanic. In T. Cox \& R. L. Beale (Eds.), Developing competen cy to manage diversity: Readings, cases and activities. San Francisco: Barrett-Ko ehler.

Denner, J., Werner, L., Bean, S., \& Campe, S. (2005). The Girls Creating Games Program: Strategies for engaging middle-school girls in information technology. Frontiers, 26(1), 90-102.

Dobosenski, L. (2001). Girls and computer technology: Building skills and improving attitudes through a girls' computer club. Library Talk, 14(4), 12-16.

Dudley-Sponaugle, A., Goode, E., Schroeder-Thomas, C., \& Trajkovski, G. (2003). New faculty contributions toward enhancing diversity. Journal of Computing Sciences in Colleges, 18, 171 - 173.

Ehn, P. (1988). Work-oriented design of computer artifacts. Stockholm: Almquist \& Wiksell International.

Fountain, J. E. (2000). Constructing the information society: Women, information technology, and design. Technology in Society, 22, 45-62.

Frauenheim, E. (2004). Students saying no to computer science. Retrieved from http://news.zdnet.com/2100-3513 22-5306096.html

Frieze, C., Blum, L., \& Dias, M. B. (2006). Culture and environment as determinants of women's participation in computing: Revealing the "women-CS fit." ACM SIGCSE Bulletin, 38(1), 22 - 26.

Gasson, S., and Agosto, D. E. (2008). Millennial students \& technology use: Implications for undergraduate education. In Education in HCI: HCI in Education - The HCIC 2008 Winter Workshop. Human Computer Interaction Consortium, Snow Mountain Ranch, Fraser, Colorado, February 2, 2008.

Geier, R., Blumenfeld, P., Marx, R., Krajcik, J., Fishman, B., \& Soloway, E. (2004). Standardized test outcomes of urb an students participating in standards and project based science curricula. Proceedings of the 6th International Conference on Learning Sciences ICLS '04, 206 - 213.

Guzman, I. R., Sharif, R. M., Blanchard, T. J., Ellis, G. S., \& Stanton, J. M. (2005). What attracts women to the IT field? The first process of occupational socialization. Proceedings of the Eleventh Americas Conference on Information Systems, Aug 11-14, Omaha, NE.

Heidegger, M. (1962). Being and time. New York: Harper \& Row. 
Honey, M., Moeller, B., Brunner, C., Bennett, D., Clements, P., \& Hawkins, J. (1991). Girls and design: Exploring the question of technological imagination. Center for Technology in Education Technical Report No. 17, 1-12.

Jackson, L. A., Ervin, K. S., Gardner, P. D., \& Schmitt, N. (2001). Gender and the Internet: Women communicating and men searching. Sex Roles, 44, 363-379.

Jepson, A., \& Perl, T. (2002). Priming the pipeline. Inroads SIGCSE Bulletin, 34(2), 36-39.

Jordan, B. (1989). Cosmopolitical obstetrics: Some insights from the training of traditional midwives. Social Science and Medicine, 28, 925-944.

Joshi, K. D., \& Schmidt, N. L. (2006). Is the information systems profession gendered? Charact erization of IS professionals and IS career. ACM SIGMIS Database, 37(4), 26 - 41.

Katz, S., Allbritton, D., Aronis, J., Wilson, \& Soffa, M. L. (2006). Gender, achievement, and persistence in an undergradu ate computer science program. ACM SIGMIS Database, 37(4), 42 - 57.

Kekelis, L. S., Ancheta, R. W., \& Countryman, J. (2005). Role models make a difference: A recipe for success. AWIS Magazine, 34(3), 17-24.

Kirk, M., \& Zander, C. (2002). Bridging the digital divide by co-creating a collaborative computer science classroom. Journal of Computing Sciences in Colleges, 18, 117 - 125.

Kvavik, R. (2005). Convenience, communications, and control: How students use technology. In D. G. Oblinger \& J. L. Oblinger (Eds.), Educating the net generation (7.1-7.20). Washington: Educause. Retrieved from http://www.educause.edu/educatingthenetgen/

Lave, J., \& Wenger, E. (1991). Situated learning: Legitimate peripheral participation. Cambridge: Cambridge University Press.

Lewis, S., McKay, J., \& Lang, C. (2006). The next wave of gender projects in IT curriculum teaching at universities. Proceedings of the 8th Australian Conference on Computing Education, 52, 135 - 142.

Little, J. C., Granger, M., Adams, E. S., Holvikivi, J., Lippert, S. K., Walker, H. M., \& Young, A. (2001). Integrating cultural issues into the computer and information technology curriculum. Annual Joint Conference Integrating Technology into Computer Science Education, 136 - 154.

Madigan, E. M., Goodfellow, M., \& Stone, J. A. (2007). Gender, perceptions, and reality: Technological literacy among first-year students. Proceedings of the 38th SIGCSE Technical Symposium on Computer Science Education, Covington, Kentucky, 410 - 414.

Margolis, J., \& Fisher, A. (2002). Unlocking the clubhouse: Women in computing. Cambridge, MA: MT Press.

May, G. S., \& Chubin, D. E. (2003). A retrospective on undergraduate engineering success for underrepresented minority students. Journal of Engineering Education, 92, 27-39.

May field, K. (2001, December 01). IT: The industry without women. Wired News. Retrieved from http://www.wired.com/news/women/0,1540,48733,00.html

McDonald, M. (2004, August 16). A few good women: Tech firms want more female computer whizzes. U.S. News \& World Report. Retrieved from http://www.usnews.com/usnews/biztech/articles/040816/16eeg eeks.htm

Moorman, P., \& Johnson, E. (2003). Still a stranger here: Attitudes among secondary school students towards computer science. ITiCSE '03 (Proceedings of the 8th annual conference on Innovation and technology in computer science education, 2003, Thessaloniki, Greece, June 30 - July 02, 2003), 193197.

National Science Foundation, Division of Sciences Resource Statistics. (2006). Women, minorities, and persons with disabilities in science and engineering: 2006. Retrieved from

http://www.nsf.gov/statistics/wmpd/underdeg.htm 
Oblinger, D. G., \& Oblinger, J. L. (2006). Is it age or IT? First steps toward understanding the Net Generation. In D. G. Oblinger \& J. L. Oblinger (Eds.), Educating the Net Generation, (2. 1-2.20). Washington: Educause. Available at: http://www.educause.edu/educatingthenetgen/

Orr, J. E. (1996). Talking about machines: An ethnography of a modern job. Ithaca, NY: ILR Press.

Othman, M., \& Latih, R. (2006). Women in computer science: No shortage here! Communications of the $A C M, 49(3), 111-114$.

Payton, F. C. (2004). Making STEM careers more accessible. Black Issues in Higher Education, 21, 4.

Payton, F. C., \& Jackson, C. (1999). Ethnic diversity in IS: What are current Ph.D. students saying? ACM SIGCPR Computer Personnel, 20(3), 27 - 39.

Payton, F. C., \& White, S. D. (2003). Views from the field on mentoring and roles of effective networks for minority $\Pi$ doctoral students. Special Interest Group on Computer Personnel Research Annual Conference. Proceedings of the 2003 SIGMIS Conference on Computer Personnel Research: Freedom in Philadelphia--Leveraging Differences and Diversity in the IT Workforce, 123 - 129.

Perelman, D. (2007, March 16). Report: Tech's gender gap widened by uninviting workplace. ACM TechNews.

Pincus, A. (1997). America's new deficit: The shortage of information technology workers. U. S. Department of Commerce. [Speech delivered Sept. 29, 1997]. Retrieved from http://www.technology.gov/speeches/p techwork.htm

Prensky, M. (2001). Digital native, digital immigrants. On the Horizon, 9(5), 1 - 5.

Rettenmayer, J., Berry, R., \& Ellis, S. (2007). The image of the information system profession: An investigation of gender differences. Journal of Computing Sciences in Colleges, 22(5), 46 - 51.

Schofield, J. W. (1995). Computers and classroom culture. New York: Cambridge.

Schön, D. A. (1983). The reflective practitioner: How professionals think in action. New York: Basic Books.

Schön, D. A. (1990). Educating the reflective practitioner: Toward a new design for teaching and learning in the professions. San Francisco: Jossey-Bass.

Stephenson, P., Miguel, L., Peckham, J., Hervé, J. Y., \& Hutt, R. (2007). Using undergraduate interdisciplinary research to promote computer science. Journal of Computing Sciences in Colleges, 22, 98 104.

Subrahmanyam, K., \& Green field, P. (1998). Computer games for girls: What makes them play? In J. Cassell \& H. Jenkins (Eds.), From Barbie to Mortal Kombat: Gender and computer games (pp. 46-71). Cambridge, MA: MIT.

Tapia, A. H., \& Kvasny, L. (2004). Recruitment is never enough: Retention of women and minorities in the IT workplace. SIGMIS '04, Apr 22-24, Tuscan, Arizona, 84 - 91.

Thomas, R., \& Allen, A. (2006). Gender differences in students' perceptions of in form ation technology as a career. Journal of Information Technology Education, 5, 165-178. Retrieved from http://jite.org/documents/Vol5/v5p165-178Thomas157.pdf

Turkle, S. (1988). Computational reticence: Why women fear the intimate machine. In C. Kramarae (Ed.) Technology and women's voices: Keeping in touch (pp. 41-61). New York: Routledge \& Kegan Paul.

United States Census Bureau. (2007). American FactFinder. Available online at: http://fact finder.census.gov/servlet/SAFFFacts? $\mathrm{sse}=\mathrm{on}$

Verbick, T. (2002) Women, technology, and gender bias. Journal of Computing Sciences in Colleges, $17,240-250$.

Vegso, J. (2005). Interest in CS as a major drops among incoming freshmen. Computing Research News, 17(3). Available online at: http://www.cra.org/CRN/articles/may05/vegso. 
Zur, E., Irani, L., Barker, L., \& Guzdial, M. (2005). Contrasting women's experiences in computer science at different institutions. Proceedings of the $36^{\text {th }}$ SIGCSE Technical Symposium on Computer Science Education, 63-64.

\section{Biographies}

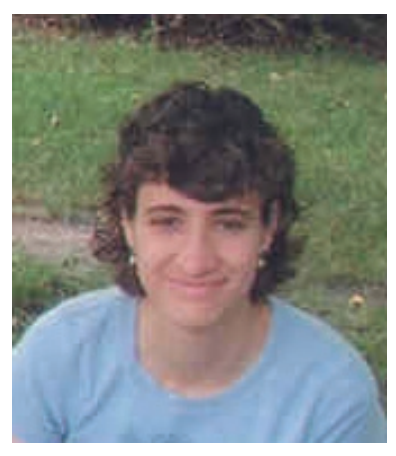

Denise E Agosto, Ph.D., is an associate professor in the College of Information Science \& Technology at Drexel University. Her research interests include gender and information use, youth information behavior, public libraries, and multicultural issues in youth library services. She has published more than 50 articles, book chapters, and entries in scholarly reference works in these areas.

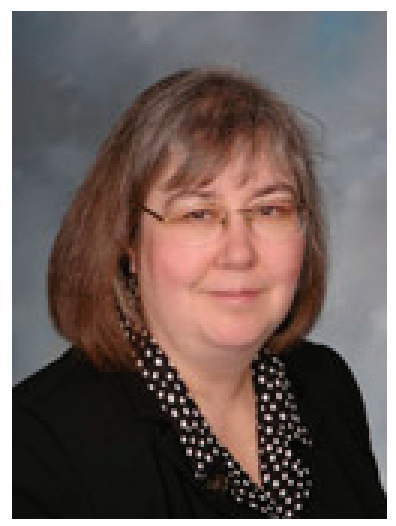

Susan Gasson, Ph.D., is Associate Professor at the iSchool at Drexel University, Philadelphia. Following a prior career in software engineering and management, Dr. Gasson brings an extensive knowledge of technology issues and engineering environments to her teaching and research. Her research interests focus on methods for stakeholder inclusion and the integration of multiple worldviews in information system design and organizational change that spans communities of practice. Dr. Gasson is the recipient of an NSF Career Award for her project "Distributed Cooperation in Boundary-Spanning IS Design."

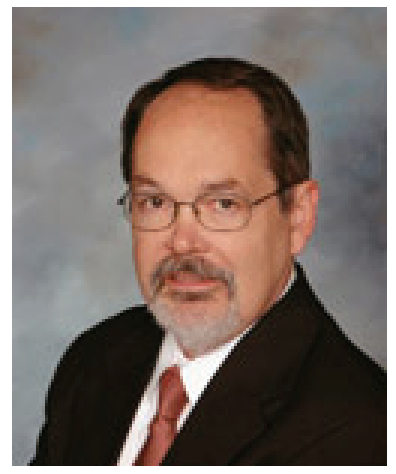

Michael E Atwood, Ph.D., is the Associate Dean of Drexel University's College of Information Science \& T echnology. He coordinates IST's research programs and IST's undergraduate and graduate program curricula. One area of current research is understanding how cont extual factors influence how someone perceives and responds to information. 